American Journal of Agricultural and Biological Sciences 4 (1): 24-31, 2009

ISSN 1557-4989

(C) 2009 Science Publications

\title{
Hard Coal Fly Ash and Silica-Effect of Fine Particulate Matter Deposits on Brassica chinensis
}

\author{
${ }^{1}$ Christian Ulrichs, ${ }^{2}$ Uwe Schmidt, ${ }^{1}$ Tanja Mucha-Pelzer, ${ }^{2}$ Arunava Goswami and ${ }^{3}$ Inga Mewis \\ ${ }^{1}$ Section Urban Plant Ecophysiology, Institute for Horticultural Sciences, \\ Humboldt University Berlin, Lentzeallee 55/57, 14195 Berlin, Germany \\ ${ }^{2}$ Section Biosystem Techniques, Institute for Horticultural Sciences, \\ Humboldt University Berlin, Lentzeallee 55/57, 14195 Berlin, Germany \\ ${ }^{3}$ Biological Sciences Division, \\ Indian Statistical Institute, 203 B. T. Road, Calcutta, West Bengal, India
}

\begin{abstract}
Problem statement: One focus in recent atmospheric pollution research is on fine Particle Matter (PM), especially as result of increasing traffic and anthropogenic activity in urban areas. Here, the impact on animal and human health has been in the center of many studies. Despite the fact that PM depositions can affect plants on the long term, there are only few studies about the impact on plants conducted. Approach: Therefore we studied the impact of PM on plants, using naturally occurring silica dusts (diatomaceous earth) and hard Coal Fly Ash (CFA) from burning processes. Dusts were applied onto Brassica chinensis L. using a simple duster (covering upper leaf surfaces) or electrostatically (covering leaf upper and -underside). Results: Main components of the tested CFA are $\mathrm{SO}_{4}{ }^{2-}, \mathrm{K}, \mathrm{Ca}$ and $\mathrm{NH}_{4+}$. The $\mathrm{pH}$ value of eluates was found to be around 9.5 in CFA and 5.7 in silica. $B$. chinensis was insensitive towards the high $\mathrm{pH}$ and showed no growth reduction when grown in silica or CFA substrate. PM deposition on leaf surfaces results through shading in a reduced photosynthetic activity. The reduction is relatively higher at higher light intensities. Photosynthesis stays reduced after removal of silica PM from leaf surfaces. We assume that stomata get cloaked by small particles and that silica absorbs lipids from the epicuticle resulting in a general stress reaction. Smaller sized silica particles resulted in a higher reduction of $\mathrm{CO}_{2}$-absorption. Next to particle size is the photosynthesis negatively correlated with exposure time for silica PM. The chlorophyll fluorescence data indicate that dust-covered leaves exhibited significantly lower quantum yield of PS II and a reduced quantum efficiency of PS II and therefore supported the gas exchange data. Conclusion: Reduced photosynthetic performance would be expected to reduce growth and productivity of B. chinensis. In contrast to silica hard coal fly ash showed only a reduction of photosynthesis through shading but did not have any long time effects after washing them off.
\end{abstract}

Key words: Diatomaceous earth, gas exchange, particulate matter, $\mathrm{PM}_{10}$, photosynthesis, electrostatic

\section{INTRODUCTION}

Research on atmospheric pollution and its impact on plants has focused predominantly on phototoxic elements such as $\mathrm{NO}_{2}, \mathrm{O}_{3}$ and $\mathrm{SO}_{2}{ }^{[1]}$. Recently, public awareness has been raised to $\mathrm{CO}_{2}$-problems and fine Particle Matter (PM), especially as result of increasing traffic and anthropogenic activity in urban areas. Therefore, in the last few years the research on the effect of PM on animals, including human being and environment, in Germany and all over the world is increasing. In the meantime, the European Union (EU) raised threshold safety levels for particulate matter in the air of urban areas. It has been widely estimated that most EU countries might not be able to maintain acceptable limits in many places due to ever-increasing pollution and growth ${ }^{[2]}$. The environmental pollution with fine PM is in less developed countries even higher.

It must be noted, that while numerous studies are available in the literature on the effects of PM on human health, there are only few studies about their effects on vegetation. Most of these investigations are in urban ecology and related to the research on the airpurifying capacities of urban green. The extent of damage caused by PM depositions affecting plants' physiological processes is often not considered. This is

Corresponding Author: Christian Ulrichs, Section Urban Plant Ecophysiology, Institute for Horticultural Sciences, Humboldt University Berlin, Lentzeallee 55/57, 14195 Berlin, Germany Tel: +49 (30) 31471387 
surprising considering the fact that heavy PM depositions on plants are known to cause long term adverse effects, including reduced diversity ${ }^{[3]}$.

Due to a heterogeneous composition of different naturally occurring PM it is often very difficult to examine the effects on the vegetation in specific experimental settings. Some silica PM derived from rock in inland settings and from shells or algae in costal areas are relatively inert in nature ${ }^{[4,5]}$. Other PM like limestone quarry dusts are highly alkaline ${ }^{[6]}$. PM in cities are derived from a mixture of anthropogenic and natural sources. In order to ascertain plantphysiological reactions due to PM exposure, we have used in our experiments naturally occurring PM with known chemical and physical compositions.

Hard Coal Fly Ash (CFA) is a by-product from power plants burning hard coal. In Germany annually 4.5 million tons of CFA are produced. Maximum emission levels are regulated by the "Großfeuerungsanlagenverordnung" (GFAVO) ${ }^{[7]}$. CFA particles in the fume gases of coal-fired power stations are held back by electrostatic filters. Such filtering units are installed in Germany in the 60th of last century, but efficiency has increased since then and as a result, CFA are produced in great qualities. In Europe, CFA collected in filters are mainly used as additive in building materials (concrete and cement). The use of CFA as naturally occurring additives has been supported in the building materials industry after careful examination and is described by the Federal association of power station by-products as natural resource. In the US alone each year over 118 million tons of coal combustion products are produced ${ }^{[8]}$. In India the figure was about 90 million ton during 1995 and is likely to exceed 140 million tons in $2020^{[9]}$. Percentage utilization of fly ash differs between countries between $95 \%$ in Belgium and the Netherlands ${ }^{[10]}$ and $3 \%$ in India in the $1990 \mathrm{~s}^{[11]}$. The low level of utilization is contributed to a lack of cost effective-technologies. Unused CFA is often deposited in quarries and open land pits and easily drifted away or not collected at all and released in the environment.

The earth's crust consists of more than $90 \%$ silicates whereas the Earth's mantle is nearly completely made of silicates. The frequently available mineral quartz $\left(\mathrm{SiO}_{2}\right)$ ranks first in Germany in the category of the oxides and in the Anglo American bibliography is counted amongst the silicates. Silica PM originates within inland ranges by decomposition from quartz rock and in close proximity to the coast, however, originates predominantly from shells and flint algae. Such fine material made up of the fossilized skeletons of siliceous marine and fresh water organisms, particularly diatoms and other algae are called diatomaceous earth. Diatomaceous Earths (DE) are well known as naturally occurring insecticides ${ }^{[12,13]}$. Because of increasing pesticide problems the use of DE based products become more and more interesting for horticultural crop production systems ${ }^{[14]}$.

Such natural occurring insecticides are nowadays applied as PM onto plant surfaces in Colombia in the floriculture industry, in India onto vegetables and in Germany in greenhouse production systems. Plant responses however, still remain till today unknown.

\section{MATERIALS AND METHODS}

PM can impact plants directly by covering aboveground parts of the vegetation or indirectly over the soil and the root systems. Therefore, we conducted experiments were particles were mixed into growth substrate as well as on plant leafs.

Particulate matter formulations: CFA has been obtained from BauMineral $\mathrm{GmbH}$ in Germany. The natural silica PM used in the experiments has been diatomaceous earth, supplied from Bein $\mathrm{GmbH}$ in Eiterfeld, Germany. The physical and chemical characteristics of the used PM types are given in Table 1.

Silica and hard coal fly ash particulate matter mixed into substrates: The evaluation of gardening culture substrates and pollutants takes place usually by means of germ plant tests. It has been found that the maximum fly ash limit value is $50 \mathrm{mg} \mathrm{m}^{-3}$ fume gas $^{[7]}$. This value was converted into the dose per unit surface area. The baseline value $\left(2.5 \mathrm{mg} \mathrm{CFA} / 50 \mathrm{~cm}^{2}\right)$ and several multiples of the baseline value $(5,25,50 \mathrm{mg})$ were applied daily on the plant substrate based on the pot surface over a period of 12 days. The attempt was made for eightfold repetition and data were analyzed over a total period of four weeks. During the entire duration of testing, however particularly after each CFA treatment, a demand-driven irrigation was applied.

Table 1: Physical and chemical characteristics of particulate matter

\begin{tabular}{lll}
\hline & Hard coal fly ash & Silica \\
\hline $\mathrm{pH}$-value & 9.52 & $7.2-8.2$ \\
$\mathrm{Mean}$ & $5.56 \mu \mathrm{m}$ \\
$\mathrm{SiO}_{2}$ & $5.6 \mu \mathrm{m}$ & $7.5 \%$ \\
$\mathrm{Al}$ & $\mathrm{Nd}$ & $4.8 \%$ \\
$\mathrm{Fe}$ & $\mathrm{Nd}$ & $4.7 \%$ \\
$\mathrm{~K}$ & $0.006 \mathrm{mg}^{-1}$ & $1.3 \%$ \\
$\mathrm{Ca}$ & $30 \mathrm{mg}^{-1}$ & $0.8 \%$ \\
$\mathrm{Mg}$ & $110 \mathrm{mg}^{-1}$ & $0.8 \%$ \\
$\mathrm{Na}$ & $6.4 \mathrm{mg}^{-1}$ & $0.3 \%$ \\
$\mathrm{SO}_{4}{ }^{2-}$ & $36 \mathrm{mg}^{-1}$ & $\mathrm{nd}$ \\
$\mathrm{NH}_{4+}$ & $462 \mathrm{mg}^{-1}$ & $\mathrm{nd}$ \\
Other elements & $14.8 \mathrm{mg}^{-1}$ & $0.3 \%$ \\
\hline
\end{tabular}

(nd $=$ not detectable; $*=50 \%$ of the particles contain this diameter particles) 
In order to prevent washing of CFA, the pots were placed in petri dishes. The surplus water caught in the petri plates was reinforced back and transferred daily into the pot. We used Pak Choi (Brassica rapa chinensis L.) as test plants. B. chinensis is a fast growing tropical crop commonly grown in peri-urban areas of tropical SE-Asia were it is often subjected to PM depositions. All plants were cultivated under standardized conditions in a climatic chamber $(10 \mathrm{k}$ lux intensity exposure to light- for $12 \mathrm{~h}$ a day; $25^{\circ} \mathrm{C}$ by daytime and $20^{\circ} \mathrm{C}$ at night). As substrate we used a clay enriched soil from the company Gramoflor (5.2$6.0 \mathrm{pH}, \mathrm{N}: 90-210 \mathrm{mg}^{-1}, \mathrm{P}_{2} \mathrm{O}_{5}: 140-230 \mathrm{mg}, \mathrm{K}_{2} \mathrm{O}: 190-$ 310 and $0.7-1.2 \mathrm{~g}^{-1}$ salt). Two seeds of B. chinensis were sown into a plastic pot with a diameter of $8 \mathrm{~cm}$ $\left(50.27 \mathrm{~cm}^{2}\right.$ surface). To determine the $\mathrm{pH}$ value, in every case, $10 \mathrm{~g}$ substrate was weighed and blended in a plastic bottle with $50 \mathrm{~mL} 0.1 \%$ a $\mathrm{KCl}$ solution. The $\mathrm{pH}$ value was determined after half hour vigorous mixing. The identical setup was used to test the impact of silica PM on plant growth and vigour.

Application of pm onto plant surfaces: CFA has been applied on 4 week old $B$. chinensis plants (cultivated as described previously) using a BOBBY duster (Agranlan Company) until a dense covering of the upper leaves. CFA has been removed carefully after $48 \mathrm{~h}$ with pressurized air.

Silica PM was applied electrostatically with a quantity of approximately $1 \mathrm{~g} \mathrm{~m}^{-2}$ on leaves of the tropical vegetable B. chinensis. In this process, a uniform PM layer was produced covering the leaves' upper and lower surfaces (Fig. 1). The application technique has been described previously in greater detail $^{[4]}$. The PM cover was kept for $24 / 48 \mathrm{~h}$ on the plants and were then washed off softly with distilled water.

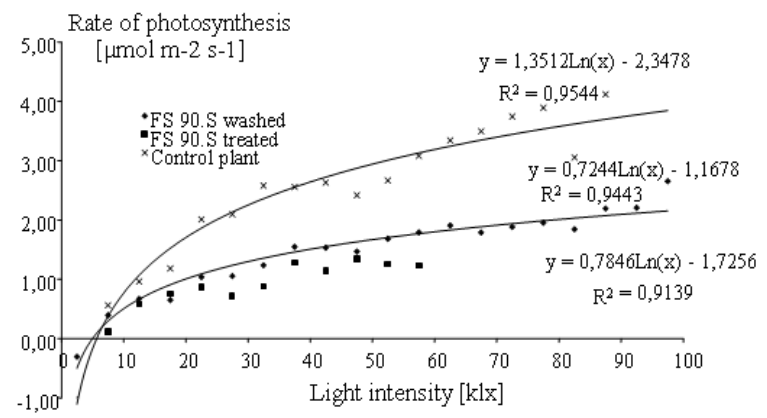

Fig. 1: Photosynthesis rate of Brassica chinensis (a) after treatment with natural silica PM (type FS90.S); (b) after removing silica PM by washing and (c) in untreated control plants
When examined under light microscope, very small amount of PM residues on the upper and lower leaf surfaces were found.

All plants topical treated with PM were kept at Humboldt University Berlin in a newly developed gas tide chamber system, BIOBOX. The BIOBOX is an experimental plant culture system, which excludes the effects of outside air completely. It offers reproducible growth conditions and is equipped for continuous $\mathrm{CO}_{2-}$ and $\mathrm{CO}_{2}$ gas change measurements. The plants occupied a volume of $54 \mathrm{~L}$ and offers Photosynthetically Active Radiation (PAR) up to $400 \mu \mathrm{mol}$. The water evaporated was condensed, collected and returned into the plant culture substrate, so that its water content remains constant. The contents of $\mathrm{O}_{2}$ and $\mathrm{CO}_{2}$ of air were measured and kept constant by addition and/or removal of $\mathrm{O}_{2}$ and $\mathrm{CO}_{2}$ to and/or from air so that the gas change efficiency of the plants is unaltered. With this modification, a correct measurement of photosynthesis and transpiration efficiency of the plants was possible ${ }^{[15,16]}$. Experiments have been repeated eight times using a maximum of three plants each time in the BIOBOX. Leaf area has been calculated afterwards by scanning the leaves using Sigma ScanPro software.

Fluorescence measurements: Chlorophyll fluorescence was determined with afield portable, pulse amplitude, modulated fluorometer (PAM-2000. Walz). Fluorometer operation and data processing were conducted with a palmtop computer and measurements were made on the lamina, midway between the base and tip of mature leaves. The potential quantum yield of PSII (Fv/Fm) was measured after $15 \mathrm{~min}$ dark adaptation. This period of predarkening was found to be sufficient for a complete relaxation of the fast relaxing components of non-photochemical quenching ${ }^{[17]}$. Measurements of chlorophyll fluorescence were made under ambient conditions at saturating Photosynthetic Photon Flux Density on the same leaves on which gas exchange measurements were made. At each site, 20 measurements were made per treatment.

Statistical analyses: Data were subjected to analysis of variance and posthoc to Tukey's HSD test to detect for differences between treatments $(\mathrm{p}<0.05)$. We used the statistical software package SYSTAT version 12 .

\section{RESULTS}

Hard coal fly ash is a smell less, grey, fine-grained and powdery substance, which consists mainly of spherical, glassy particles. Main components of the tested CFA are $\mathrm{SO}_{4}{ }^{2-}, \mathrm{K}, \mathrm{Ca}$ and $\mathrm{NH}_{4+}$ (Table 1). 
Am. J. Agri. \& Biol. Sci., 4 (1): 24-31, 2009

Table 2: $\mathrm{pH}$ measurement of different Gramoflor- coal fly ash/silica mixtures

Substrate concentration (\%) mixed with gram flour

\begin{tabular}{|c|c|c|c|c|c|c|c|}
\hline Substrate & 0 & 1 & 5 & $10 \mathrm{pH}$ & 20 & 50 & 100 \\
\hline$\overline{\mathrm{CFA}}$ & $5.60 \mathrm{a}$ & $5.64 a$ & $4.81 \mathrm{a}$ & $5.29 \mathrm{~b}$ & $6.31 \mathrm{c}$ & $7.60 \mathrm{~d}$ & $9.26 \mathrm{e}$ \\
\hline Silica & $5.65 \mathrm{a}$ & $5.65 \mathrm{a}$ & $5.70 \mathrm{a}$ & $5.55 \mathrm{a}$ & $5.60 \mathrm{a}$ & $5.60 \mathrm{a}$ & $5.70 \mathrm{a}$ \\
\hline
\end{tabular}

Table 3: Leaf surfaces and photosynthesis rates after the treatment of Brassica chinensis with $\mathrm{SiO}_{2}-\mathrm{PM}$

\begin{tabular}{lcccc}
\hline & $\begin{array}{l}\text { Leaf } \\
\text { surface } \\
{\left[\mathrm{cm}^{2}\right]}\end{array}$ & $\begin{array}{l}\mathrm{CO}_{2} \text {-Absorption } \\
\text { during } \\
\text { treatment } \\
{\left[\mathrm{ml}^{*} \mathrm{~cm}^{-2} \mathrm{~h}^{-1}\right]}\end{array}$ & $\begin{array}{l}\mathrm{CO}_{2} \text {-Absorption } \\
\text { during the } \\
\text { treatment in } \\
\% \text { of control }\end{array}$ & $\begin{array}{l}\mathrm{CO}_{2} \text {-Absorption } \\
\text { after cleaning } \\
\text { of the plants } \\
\text { in \% of control }\end{array}$ \\
\hline Control & 248 & 0.112 & 100 & 100 \\
Treatment $2 \mathrm{~h}$ & 248 & 0.047 & 42 & 92 \\
Treatment 24 h & 267 & 0.040 & 35 & 80 \\
Treatment 48 h & 257 & 0.048 & 43 & 74 \\
Treatment 72 h & 306 & 0.037 & 33 & 62 \\
\hline
\end{tabular}

In the analysis of eluates the $\mathrm{pH}$ value for CFA was found to be around 9.3 (Table 2). Therefore, CFA could have unfavourable effects on the condition of groundwater, since some of the aforesaid mineral materials can contaminate ground waters. The "Hygiene-Institute" at Ruhr University (Gelsenkirchen, Germany) analyzed the soil eluate from the paging and washing processes and they found discharging heavy metals and metal ions in the surface water. The $\mathrm{pH}$ value in the substrate rose as expected with the increased content of CFA in the substrate (Table 2). However, since we did not add fertilizer plant height is, because of nutrient deficiency, lowest when plants are grown in a $100 \%$ silica substrate. This is not the case when Gramoflor has been mixed with CFA. CFA did not affect plant height, even if the $\mathrm{pH}$-value in pure CFA substrate has not been favourable. However, total plant dry mass has been significant lower when plants are grown in $100 \%$ CFA (Table 5).

In our experiments photosynthetic rate was significantly reduced after application of silica. At a medium light intensity the reduction was about $50 \%$ compared to the control (Fig. 1). The rate of photosynthesis stayed even after removal of dusts from the surface reduced (Fig. 1), which might be an indication for stomata clogging. The treatment with smaller particle sizes dust led even to a stronger reduction of photosynthesis (Fig. 2).

However, longer the silica stayed on the surface, higher was the reduction of $\mathrm{CO}_{2}$-absorption as indicator for photosynthetic activity (Table 3 ). Even if we could not find under the light microscope any major DE residues after washing them, we might have damaged or even removed the epicuticle of the plant partially. This would lead to a general stress reaction including higher respiration- and transpiration rates.
Table 4: Photosystem II quantum yield and quantum efficiency of PS II $(\mathrm{Fv} / \mathrm{Fm})$ of upper leaf surfaces of Brassica chinensis uncovered or covered with CFA or Silica (FS90.S)

\begin{tabular}{lccr}
\hline & \multicolumn{2}{c}{ Treatment } & \\
& - & \\
Factor & Untreated & Silica treated & CFA treated \\
\hline Yield $\left(\Delta \mathrm{F}_{\mathrm{v}} / \mathrm{F}_{\mathrm{m}}\right)$ & $0.41 \mathrm{a}$ & $0.38 \mathrm{ab}$ & $0.32 \mathrm{~b}$ \\
$\mathrm{~F}_{\mathrm{v}} / \mathrm{F}_{\mathrm{m}}$ & $0.80 \mathrm{a}$ & $0.77 \mathrm{a}$ & $0.76 \mathrm{a}$ \\
\hline
\end{tabular}

Different letters indicate significant differences between treatments within factor, Tukey HSD $p<0.05$

Table 5: Plant growth parameter of Brassica chinensis 6 weeks after seeding depending from different soil-silica/fly ash mixtures

Plant dry mass

Substrate mixture $(\%) \quad$ Plant height $(\mathrm{cm}) \quad$ including roots $(\mathrm{g})$

Gramoflor/Silica (FS90.s)

$\begin{array}{lll}100 / 0 & 28.5 \mathrm{a} & 6.55 \mathrm{a} \\ 50 / 50 & 31.0 \mathrm{~b} & 7.33 \mathrm{~b}\end{array}$

$0 / 100 \quad 22.1 \mathrm{c} \quad 3.95 \mathrm{c}$

$\begin{array}{lll}\text { Gramoflor/CFA } & 29.0 \mathrm{a} & 7.02 \mathrm{a}\end{array}$

\begin{tabular}{lll}
$50 / 50$ & $29.3 \mathrm{a}$ & $7.22 \mathrm{a}$ \\
\hline
\end{tabular}

$0 / 100 \quad 27.9 \mathrm{a} \quad 6.10 \mathrm{~b}$

Different letters indicate significant differences between mixtures with factor with Tukey's HSD, $\mathrm{p}<0.05$

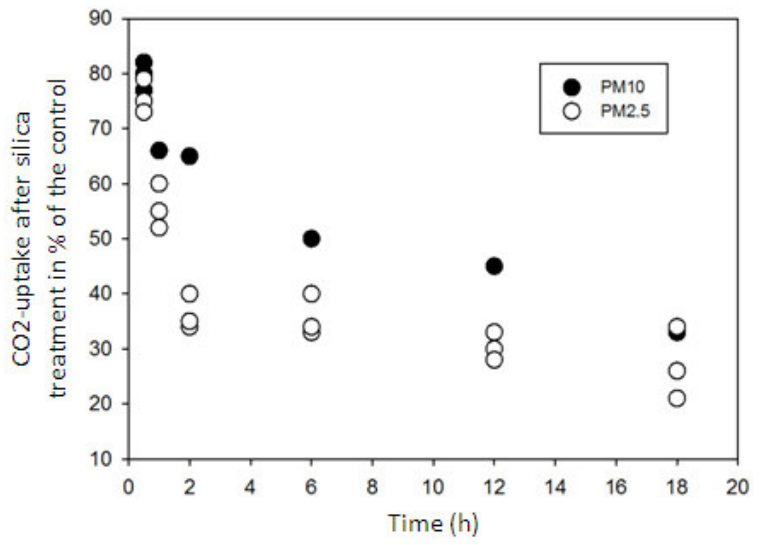

Fig. 2: $\mathrm{CO}_{2-}$ absorption data from Brassica chinensis after treatment with $\mathrm{PM}_{10}$ and $\mathrm{PM}_{2.5}$ silica

Decreases in quantum yield of PS II through PS II in dust covered leaves (Table 4) were consistent with reduced $\mathrm{CO}_{2}$ exchange, thereby clearly indicating that photosynthetic performance was significantly reduced by CFA and silica PM coverage. Photochemical efficiency $(\mathrm{Fv} / \mathrm{Fm})$ values across all treatments in this study varied from $0.32-0.80$ which is typical of nearly completely relaxed PS II ${ }^{[51]}$.

The application of CFA onto leaves showed no effect over a period of four weeks with regard to root rating, habitus rating, growth height, leave number and dry weight development. 


\section{DISCUSSION}

Effect on soil properties: PM drift resulting from agricultural liming and fertilization can have an eutrophication effect on nearby soils. For decades, numerous researchers have looked into the possible use of CFA in agriculture ${ }^{[18-20]}$. In various investigations CFA has been used as substrate and data have been analyzed from the viewpoint of plant nutrition ${ }^{[21-23]}$.

There is evidence that high $\mathrm{pH}$ values and phytotoxic boron contents hinder the use of CFA in the field level ${ }^{[24]}$. Only after sufficient precipitation, the phytotoxic characteristics of the substrates with very high CFA content decreased. Other researchers claimed that higher boron contents in CFA have soilameliorating characteristics ${ }^{[24]}$. Some scientists demonstrated the phytotoxic boron effect due to fly ash application ${ }^{[23]}$. Higher content of boron was found in the leaves causing drying up of the edges. However, no such damage was recognizable in the case of B. chinensis (Table 5) and similar results are reported by other researchers ${ }^{[33]}$. This could be to due to the relatively short duration of four weeks experimental time. A further explanation lies probably in the very high CFA proportions in the substrate $(90-95 \%)$ used by other groups ${ }^{[23]}$. The effect of different portions of fly ash in the substrate has been tested by on the crop yield of tomatoes ${ }^{[34]}$. Here an increase of the CFA concentration in the soil increased the availability of carbonates, sulphates, chloride, B, P, K, Ca, Mg, Mn, $\mathrm{Cu}$ and $\mathrm{Zn}$. Also the dewatering capacity and the $\mathrm{pH}$ value of the soil rose. Up to a concentration of 50-60\% CFA in the soil, the crop benefits rose up to over $80 \%$. CFA differs in their composition from different sources $^{[35]}$.

It has been demonstrated that yields of soybeans could increase over up to $35 \%$ by CFA applications on sandy and clay soils in south of Ontario ${ }^{[25]}$. On the yield of corn, CFA had however no effects. Some researchers reported an increase of the health-favourable Indolyl Glucosinolate: Glucobrassicin (3-Indolylmethylglucosinolat) and Neoglucobrassicin content in yellow turnip on CFA application ${ }^{[26]}$. Moreover, it was found that increased fly ash content in the soil had positive effects on the water availability in sandy ${ }^{[27,28]}$ and coarse-grained ${ }^{[29]}$ soils.

Two research groups $^{[30,31]}$ described CFA in general as rich in calcium and thus explaining the high $\mathrm{pH}$ value we observed (Table 2). CFA often contains polychlorinated biphenyls (PCB), polycyclic aromatic hydrocarbons and various metals in the $\mathrm{mg}$ per $\mathrm{kg}$ range. The majority of field crops prefer a neutral or light acidic soil, since the solubility of most nutrients for healthy growth of the plants is highest at $\mathrm{pH}$ values between 6.3-6.8. Some plants prefer however more acidic (e.g., potatoes, strawberries) or more alkaline (e.g., cabbage) soil conditions. A pH value of clear over seven, can be achieved with 50\% CFA or more, could lead to situations with lack of nutrient for some plants. Oats showed germination delay in alkaline soils coupled with reduced yield ${ }^{[32]}$. B. chinensis was relatively insensitive to $\mathrm{pH}$-change. Plant height of B. chinensis has been highest in a 50\% mixture of Gramoflor and silica. Silica treatment increases water holding capacity of the substrate.

The conflicting results underline that comparisons of different CFA sources are meaningful only then, if the composition of the CFA is considered. The CFA composition depends not only from the source but also from parameters resulting from the coal burning process.

Various inorganic soil amendments, including silica, have been promoted as a means of improving the chemical and physical properties of certain soils. Drought-sustaining ability of soil-amendment mixtures was significantly correlated with water-holding ability, soil strength, bulk density and oxygen diffusion rate, but not correlated with either $\mathrm{pH}$ or cation exchange capacity when silica has been added to the soil ${ }^{[36]}$. The properties and behaviour observed for the amorphous complexes and the soil admixtures can be linked directly to the large specific surface area and high surface charge of the amorphous complexes. The substrate $\mathrm{pH}$ did not change after adding silica and stayed slightly acidic, therefore optimal for most plants (Table 2). Since DE is inert in nature we did not expect any interaction with nutritional values in the main substrate Gramoflor. However, silica itself does not contain nutrients necessary for plant growth. Therefore, B. chinensis plants were smaller and had less dry mass when grown in pure silica compared to control plants grown in Gramoflor (Table 5.). A mixture of 50\% Gramoflor and silica resulted in higher plants with more dry mass. This is most likely contributed to a general improvement of the substrate including a higher water holding capacity of the substrate ${ }^{[37]}$.

Impact on leave surfaces: The amount of PM naturally deposited on plant surfaces varies significantly spatiotemporally. Many of the factors responsible for the PM deposition are similar to those governing deposition of other pollutants. Generally greater surface roughness increases deposition rate ${ }^{[38]}$. This parameter is especially important at greater wind speeds ${ }^{[39]}$. Dusts affect plant physiology, both physically as well as at the chemical and biochemical level. The absolute level of dust deposition might be important for physical effects. 
It has been reported, that while dust can cause a decrease in stomatal diffusive resistance in plants ${ }^{[40]}$. Such layer of silica dust is likely to elicit direct stress response inside the plants. Studies have shown that foliage cover by $1.2 \mathrm{~g} \mathrm{~m}^{-2}$ dust alone can result in a shading coefficients of up to $0.25,0.20$ and 0.15 . The shading coefficient becomes larger when finer dust is applied ${ }^{[41]}$. Fine dust particles have also been reported to clog stomata openings ${ }^{[42,43]}$, increased leaf temperature $\mathrm{e}^{[44,45]}$ and increase transpiration ${ }^{[46]}$. Stomata diameter usually ranges from $8-12 \mu \mathrm{m}$ for crops ${ }^{[47]}$. PM size is very important as this can cause impairment of stomata functions. In the presented study, PM applied had a particle size of $5-10 \mu \mathrm{m}$ and could therefore affect the stomatal functions. Clogging the leaf stomata lowers the rate of transpiration and carbon assimilation, which finally causes a significant reduction in the photosynthesis rate. This assumption seems confirmed by our results (Fig. 1). This effect is presumably due to the closer lining of dust particles on leaf surface resulting in a greater shading effect in PAR (Fig. 2). Additionally the reduction of $\mathrm{CO}_{2}$-uptake might be caused by stomata clogging, because $\mathrm{PM}_{2.5}$ is more likely to penetrate $B$. chinensis stomata than $\mathrm{PM}_{10}$.

Diatomaceous Earths (DE) are well known natural insecticides ${ }^{[48]}$. Death of insects treated with DE is caused by disruption of the "water barrier", the waxy epicuticle of an insect ${ }^{[14]}$. Here DE particles interact with the cuticle by absorption of cuticular lipids and becoming absorbed into the cuticle ${ }^{[49,50]}$. The DE used has strong lipophilicity and weak hydrophobic characteristics. Thereby we assume that the dust gets physical absorbed on surface waxes of the leaves causing an irreversible damage. This data independently confirmed the results obtained by other researchers ${ }^{[32]}$. Leaves of $B$. chinensis are equipped with a wax coat, which prevents humidity loss.

It has been observed that the chemical interaction with the vegetation surface is impaired by the presence of water. CFA largely is not water soluble and thus the probability of chemical burn only very small. CFA dust causes blockage of the stomata under naturally conditions on the upper surfaces of the vegetation and to a smaller extent at the lower surfaces. The substantial effect probably lies thereby in a reduction of the photosynthetic product. This assumption is confirmed by findings that fly-ash dust from a coal-fired power plant affected Calamagrostis epigeios and Hypericum perforatum but the stomata were rarely blocked ${ }^{[34]}$. They suggested that the dust may act directly on the guard cells, though the mechanisms for this effect remain uncertain till date. Simultaneous depression in $\mathrm{CO}_{2}$ uptake and PS II photochemical efficiency
(Table 4), caused by CFA, have been reported for several other plant species ${ }^{[52,53]}$.

\section{REFERENCES}

1. Farmer, A.M., 1993. The effects of dust on vegetation: A review. Environ. Pollut. 79: 63-75. http://cat.inist.fr/?aModele $=$ afficheN\&cpsidt $=4458211$

2. Umweltbundesamt, 2005. Hintergrundpapier zum Thema Staub/Feinstaub (PM). http://www.braungart.com/PDFs/UBA_Hintergrun d_Feinstaub.pdf

3. Daily, G.C., 1997. Introduction: What are Ecosystem Services? In: Nature's Services: Social Dependence on Natural Ecosystems, Daily, G.C. (Ed.). Island Press, Washington DC., USA., pp: 1-10.

4. Ulrichs, Ch., F. Krause, T. Rocksch, A. Goswami and I. Mewis, 2006. Electrostatic application of inert silica dust based insecticides to plant surfaces. Comm. Appl. Biol. Sci., Ghent Univ., 71: 171-178. http://www.ncbi.nlm.nih.gov/pubmed/17390789

5. Rahman, A., D. Seth, S.K. Mukhopadhyaya, R.L. Brahmachary, Ch. Ulrichs and A. Goswami, 2009: Surface functionalized amorphous nanosilica and micro-silica with nanopores as promising tools in biomedicine. Naturwissenschaften, 96: 31-38. DOI: 10.1007/s00114-008-0445-1

6. Zaharopoulou, A., T. Lanaras and M. Arianoutsou, 1993. Influence of dust from a limestone quarry on chlorophyll degradation of the lichen Physcia adscendens (Fr.) Oliv. Bull. Environ. Contaminat. Toxicol., 50: 852-855. DOI: 10.1007/BF00209949

7. Bundesrecht, 2000. Dreizehnte Verordnung zur Durchführung des BundesImmisionsschutzgesetzes (Verordnung der Großfeuerungsanlagen- $13 . \quad \mathrm{BlmSchV}$ ). http://bundesrecht.juris.de/bundesrecht/bimschv_13 /undex.html

8. Kalyoncu, R.S., 2000. Coal Combustion Products. http://minerals.usgs.gov/minerals/pubs/commodity/ coal/874400.pdf

9. Kalra, N., M.C. Jain, H.C. Joshi, R. Choudhary, R.C. Harit, B.K. Vatsa, S.K. Sharma and S.K. Kumar, 1998. Fly ash as soil conditioner and fertilizer. Bioresourc. Technol., 64: 163-167. DOI 10.1016/S0960-8524(97)00187-9

10. Bhattacharjee, U. and T.C. Kandpal, 2002. Potential of fly ash utilisation in India. Energy, 27: 151-166. DOI: 10.1016/S0360-5442(01)00065-2

11. Bhattacharjee, U. and T.C. Kandpal, 2002. Potential of flyash utilisation in India. Energy, 27: 151-166. DOI: 10.1016/S0360-5442(01)00065-2 
12. Mewis, I. and Ch. Ulrichs, 1999. The mode of action of diatomaceous earth against stored product pests. Study of abrasive and sorptive effects. J. Pest Sci., 72: 113-121. DOI: 10.1016/S0022474X(00)00016-3

13. Ulrichs, Ch., B. Welke, T. Mucha-Pelzer, A. Goswami and I. Mewis, 2008. Effect of solid particulate matter deposits on vegetation-a review. Function. Plant Sci. Biotechnol., 2: 56-62. http://globalsciencebooks.info/JournalsSup/08FPS B_2_1.html

14. Ulrichs, Ch., I. Mewis, A. Goswami, S.D. Chatterjee, S.P. Banerjee, S. Adhikary and A. Bhattacharyya, 2006. Biodiversity-macro and micro: To be nano or not to be. Everyman's Sci., XL: 433-436. http://sciencecongress.nic.in/html/pdf/Feb_March_ 06_F1.pdf

15. Daunicht, H.J. and C. Richter, 2000. Phytosys: An advanced plant cuvette system for space experimentation. (SAE Techn. Paper 2000-012330). http://www.sae.org/technical/papers/200001-2230

16. Ulrichs, C., T. Mucha-Pelzer, E. Scobel, L. Kretschmer, R. Bauer, E. Bauer and I. Mewis, 2008. Plant protection with silica particles: Electrostatic application and impact of particle layer density on the insecticidal efficacy. Gesunde Pflanzen, 60: 29-34. DOI: 10.1007/s10343-008-0176-4

17. Tuffers, A.V., G. Naidoo and D.J. von Willert, 1999. The contribution of leaf angle to photoprotection in the mangroves Avicennia marina (Forssk.) Vierh. and bruguiera gymnorrhiza (L.) Lam. under field conditions in South Africa. Flora, 194: 267-275. http://cat.inist.fr/?aModele $=$ afficheN\&cpsidt $=10136962$

18. Page, A.L., A.A. Elseewi and I.R. Straughan, 1979. Physical and chemical properties of fly ash from coal-tired power plants with reference to environmental impacts. Residue Rev., 71: 83-120. http://www.osti.gov/energycitations/product.biblio. jsp?osti_id=6822701

19. Adriano, D.C., A.L. Page, A.A. Elseewi, A.C. Chang and I. Straughan, 1980. Utilization and disposal of fly ash and other coal residues in terrestrial ecosystems: A review. J. Environ. Qual., 9: 333-344. http://jeq.scijournals.org/cgi/content/abstract/9/3/333

20. Wong, J.W.C. and M.H. Wong 1990. Effects of fly ash on yields and elemental composition of two vegetables, Brassica parachinensis and B. chinensis. Agric. Ecosyst. Environ., 30: 251-264. DOI: 10.1016/0167-8809(90)90109-Q

21. Gupta, D.K., N.R. Upendra, R.D. Tripathi and M. Inouhe, 2002. Impacts of fly-ash on soil and plant responses. J. Plant Res., 115: 401-409. DOI: 10.1007/s10265-002-0057-3.
22. Hill, M.F. and C.A. Lamp, 1980. Use of pulverized fuel ash from victorian brown coal as a source of nutrients for pasture species. Aust. J. Exp. Agric. Anim. Hush., 20: 377-384. DOI: 10.1071/EA9800377

23. Rees, W.J. and G.H. Sidrak, 1956. Plant nutrition on fly-ash. Plant Soil, 8: 141-159. DOI: 10.1007/BF01398816.

24. Wong, J.W.C. and D.C. Su, 1997. Reutilization of coal fly-ash and sewage sludge as an artificial soilmix: effects of preincubation on soil physicochemical properties. Bioresourc. Technol., 59: 97-102. http://www.cheric.org/research/tech/periodicals/vol _view.php?seq=361503

25. Cline, J.A., M. and A. Torrenueva, 2000. Coal fly ash as a soil conditioner for field crops in southern Ontario. J. Environ. Qual., 29: 1982-1989. http://jeq.scijournals.org/cgi/content/abstract/29/6/1982

26. Anderson, J.L., D.J. Lisk and G.S. Stoewsand, 1990. Glucosinolates in rutabaga grown in soil capped over coal fly ash. J. Food Sci. Publ. Inst. Food Technol., 55: 556-557. DOI: 10.1111/j.13652621.1990.tb06810.x

27. Adriano, D.C. and J.T. Weber, 2001. Influence of fly ash on soil physical properties and turfgrass establishment. J. Environ. Qual., 30: 596-601. http://jeq.scijournals.org/cgi/content/abstract/30/2/596

28. Campbell, D.J., W.E. Fox, R.L. Aitken and L.C. Bell, 1983. Physical characteristics of sands amended with fly ash. Aust. J. Soil Res., 21: 147-154. DOI: 10.1071/SR9830147

29. Chang, A.C., L.J. Lund and J.E. Wameke, 1977. Physical properties of fly ash-amended soils. J. Environ. Qual., 6: 267-270. http://jeq.scijournals.org/cgi/content/abstract/6/3/267

30. Logan, T.J. and B.J. Harrison, 1995. Physical characteristics of alkaline stabilized sewage sludge (N-Viro soil) and their effects on soil physical properties. J. Environ. Qual., 4: 153-164. http://jeq.scijournals.org/cgi/content/abstract/24/1/153

31. Wong, J.W.C., 1995. The production of an artificial soil mix from coal fly ash and sewage sludge. Environ. Technol., 16: 741-751. http://www.ingentaconnect.com/content/tandf/envt/ 1995/00000016/00000008/art00004

32. Hofmann, E. and H.G. Von Bomhard, 1956. Vegetationsversuche Mit Verschiedenen Gaben von Steinkohlenflugasche auf Einem Boden des Ruhrgebiets. In: Steinkohlenflugasche-Einfluss auf Boden, Pflanzen und Milchkühe, Oberste-Brink, K. (Ed.). Gustav Fischer Verlag, Stuttgart. 
33. Shorrocks, V.M., 1997. The occurrence and correction of boron deficiency. Plant Soil, 193: 121-148. DOI: 10.1023/A:1004216126069

34. Khan, M.R., M.W. Khan and K. Singh, 1997. Management of root-knot disease of tomato by the application of fly ash in soil. Plant Pathol. 46: 33-43. http://pt.wkhealth.com/pt/re/plpa/abstract.0001048 9-199702000-

00003.htm;jsessionid=JglprHFQn6vv5Y0JdB6LVj F9Ybw2QKGGTQK2pSQG54Zn17MBLKLh!191 0807570 !181195628!8091!-1

35. Chen, L.C., H.F. Lam, E.J. Kim, J. Guty and M.O. Amdur, 1990. Pulmonary effects of ultrafine coal fly ash inhaled by guinea pigs. J. Toxicol. Environ. Health, 29: 169-184 http://www.osti.gov/energycitations/product.biblio. jsp?osti_id=6911813

36. Wehtje, G.R., J.N. Shaw, R.H. Walker and W. Williams, 2003. Bermudagrass growth in soil supplemented with inorganic amendments. Hortscience, 38: 613-617. http://cat.inist.fr/?aModele $=$ afficheN\&cpsidt $=15015793$

37. Li D., Y.K. Joo, N.E. Christians and D.D. Minner, 2000. Inorganic soil amendment effects on sandbased sports turf media. Crop Sci., 40: 1121-1125. http://crop.scijournals.org/cgi/content/full/40/4/1121

38. Belot, Y., A. Baille and J.L. Delmas, 1976. Modele numerique de dispersion des polluants atmospheriques en presence de couverts vegetaux. Atmospher. Environ., 10: 89-98. DOI: 10.1016/0004-6981(76)90225-0

39. Chamberlain, A.C., 1967. Transport of Lycopodium spores and other small particles to rough surfaces. Proc. R. Soc. Ser. A., 296: 45-70. http://journals.royalsociety.org/index/MM617Q468 3645673.pdf

40. Flückiger, W., H. Flückiger-Keller and J.J. Oertli, 1978. Inhibition of the regulatory ability of stomata caused by exhaust gases. Cell. Mol. Life Sci., 34: 1274-1275. DOI: 10.1007/BF01981413

41. Hirano, T., M. Kiyota and I. Aiga, 1994. Physical effects of dust on leaf physiology of cucumber and kidney bean plants. Environ. Pollut., 89: 255-261. DOI: 10.1016/0269-7491(94)00075-O

42. Jameson, W.C. and J.B. Schiel 1972. A preliminary investigation on the relationship between gypsum dust and vegetation growth. Bios, 43: 65-69. http://www.jstor.org/pss/4607105

43. Hirano, T., M. Kiyota and I. Aiga, 1995. Physical effects of dust on leaf physiology of cucumber and kidney bean plants. Environ. Pollut., 89: 255-261. DOI: 10.1016/0269-7491(94)00075-O
44. Hirano, T., M. Kiyota and I. Aiga, 1995. Physical effects of dust on leaf physiology of cucumber and kidney bean plants. Environ. Pollut., 89: 255-261. DOI: 10.1016/0269-7491(94)00075-O

45. Sharifi, M.R., A.C. Gibson and P.W. Rundel, 1997. Surface dust impacts on gas exchange in mojave desert shrubs. J. Appl. Ecol., 34: 837-846. http://www.jstor.org/pss/2405275

46. Eveling, D.W., 1969. Effects of spraying plants with suspensions of inert dusts. Ann. Appl. Biol., 64: 139-151. DOI: $10.1111 / \mathrm{j} .1744-$ 7348.1969.tb02864.x

47. Krajickova, A. and V. Mejstrik, 1984. The effect of fly-ash particles on the plugging of stomata. Environ. $\quad$ Pollut. $\quad 36$ : 83-93. http://cat.inist.fr/?aModele $=$ afficheN\&cpsidt $=8369874$

48. Ulrichs, C., S. Entenmann, A. Goswami and I. Mewis, 2006. Abrasive and hydrophilic/lipophilic effects of different inert dusts used as insecticide against the stored insect pest Sitophilus granarius L. Gesunde Pflanzen. 58: 173-181. DOI: 10.1007/s10343-0060124-0

49. Ulrichs, Ch., C. Reichmuth, T. Mucha-Pelzer and I. Mewis, 2006. Silica against insect pests under glas. Mitt. Biol. Bundesanstalt Land-und Forstw., 400: 184-185. http://www.bba.de/veroeff/mitt/pdfs/mitt400.pdf

50. Majumder, D.D., R. Banerjee, Ch. Ulrichs, I. Mewis and A. Goswami, 2007. Nano-materials: Science of bottom-up and top-down. IETE Technol. Rev. Nanotechnol. Educ. Paradigm Shift, 24: 9-25. http://www.iete.org/iete-Journal\%20$\% 20$ Vol\%2024\%20-\%20No\%20-\%201\%20$\% 202007 . p d f \#$ page $=11$

51. Naidoo, G. and D. Chirkoot, 2004. The effects of coal dust on photosynthetic performance of the mangrove, Avicennia marina in Richards Bay, South Africa. Environ. Pollut., 127: 359-366. DOI: 10.1016/j.envpol.2003.08.018

52. Demmig-Adams, B., W.W. Adams, K. Winter, A. Meyer, U. Schreiber, J. Pereira, A. Kruger, F.C. Czygan and O.L. Lange, 1989. Photochemical efficiency of photosystem II, photon yield of $\mathrm{O}_{2}$ evolution, photosynthetic capacity and carotenoid composition during the midday depression of net $\mathrm{CO}_{2}$ uptake in Arbutus unedo growing in Portugal. Planta, 177: 377-387. DOI: 10.1007/BF00403596

53. Valladares, F. and R.W. Pearcy, 1997. Interactions between water stress, sun-shade acclimation, heat tolerance and photoinhibition in the sclerophyll Heteromeles arbutifolia. Plant Cell Environ., 20: 25-36. DOI: 10.1111/j.1365-3040.1997.tb00440.x 